\title{
Impacts of high-nitrate freshwater inputs on macrotidal ecosystems. II. Specific role of the silicic acid pump in the year-round dominance of diatoms in the Bay of Brest (France)
}

\author{
Yolanda Del Amo*, Bernard Quéguiner, Paul Tréguer, Hervé Breton, Luis Lampert \\ UMR CNRS 6539 'Bioflux', Université de Bretagne Occidentale, Institut Universitaire Européen de la Mer, \\ Technopole Brest-Iroise, Place Nicolas Copernic, F-29280 Plouzané, France
}

\begin{abstract}
To assess the consequences of very-high-nitrate freshwater inputs on phytoplankton conmunity structure a complete 1993-1994 annual crele is described for the Bay of Brest (France). In contrast to other nitrate-enriched coastal ecosystons where small and non-siliceous species dominate in summer, un this well-mixed macrotidal ecosystem diatoms $>10 \mu \mathrm{m}$ dominated bloom successions in surface waters from March to September 1993. Following a small bloom of Skeletonema costatum in March, an intensive spring bloom (biogenic siluca, BSi $=1.8$ to $2 \mu \mathrm{mol} \mathrm{Si} \mathrm{l}^{-1}$ ) observed in April-May (first dominated by Thalassiosira spp. and then by Rhszosolenia spp. by late May) collapsed due to Si limitation. Although dinoflagellates developed during the decline of this spring bloom and remained abundant until late September, a new diatom-dominated population (Chaetoceros spp.) developed from the end of May untıl late September (BSi decreased from about 1 to $0.5 \mu \mathrm{mol} \mathrm{Si} \mathrm{L}^{-1}$ ). Finally, at the end of the productive period (September), a bloom dominated by the $<10 \mu \mathrm{m}$ size class, essentially due to cryptophyceans, occurred. On an annual basis, the $>10 \mu \mathrm{m}$ size class accounted for 73 to $74 \%$ of the time-weighted averages of chlorophyll $a$, of primary production, and of biogenic silica in surface waters. Finally, there is no evidence that the phytoplankton community structure of the Bay of Brest was dramatically affected by nitrate enrichment, either in terms of size structure or of diatom abundance relative to dinoflagellates (although the emergence of some undesirable species among the dinoflagellates was observed). A silicic acid (i.e. silicate) pump, specific to well-mixed coastal ecosystems, is inferred to explain the dominance of diatoms during the periods following the spring bloom. It provides a mechanism that prevents silicon loss out of the system by trapping it at the shallow watersediment interface at the end of the spring bloom. The tidally induced vertical mixing allows silicic acid from biogenic silica dissolution to become readily available for new diatom developments in surface waters
\end{abstract}

KEY WORDS: Coastal ecosystem Phytoplankton dynamics . Community structure - Diatoms Dinoflagellates Size classes - Nutrient limitation S Silicon - Eutrophication

\section{INTRODUCTION}

The long-term increase of nutrient enrichment in western European coastal waters has often been associated with eutrophication problems as well as modifi-

- Present address: Department of Ecology, Evolution and Marine Biology, Marine Science Institute, University of California, Santa Barbara, California 93106, USA.

E-mail: delamo@lifesci.lscf.ucsb.edu cations of the phytoplankton community structure (Smayda 1990, Billen et al. 1991). Increased anthropogenic inputs of nitrogen and phosphorus to rivers has led to a decline of dissolved Si:N and Si:P ratios in adjacent coastal waters, favoring potential Si limitation of diatom primary production (Meybeck \& Helmer 1989. Smayda 1990, Le Pape et al. 1996, Del Amo et al. 1997). Phytoplankton species composition is sensitive to nutrient ratios and diatoms clearly appear to be the most affected group (Officer \& Ryther 1980, Smayda 
1990, Conley \& Malone 1992). Si limitation can result in considerable modifications of the phytoplankton community structure at the species-composition level or at the size-structure level. Concerning the phytoplankton species composition, decreased diatom abundance or dominance (van Bennekom et al. 1975 , Bodeanu 1990) and widespread shifts from siliceous (diatoms) towards non-siliceous (flagellates) species (Billen et al. 1991, Fisher et al. 1992), with the possible emergence of novel and nuisance phytoplankton blooms (Smayda 1990, Anderson 1995), have been reported following $\mathrm{N}$ and $\mathrm{P}$ enrichments. The modification of the size structure of the phytoplankton community is also reflected by shifts toward smaller-sized organisms (Revelante \& Gilmartin 1978). Following the classification of Sieburth et al. (1978), 3 major pelagic size classes can be distinguished: pico- $(<2 \mu \mathrm{m})$, nano$(2-20 \mu \mathrm{m})$, and micro- $(20-200 \mu \mathrm{m})$ plankton. Although seasonal increases in primary production generally reflect the microplankton growth, pico- and nanoplankton can sometimes be significant contributors to primary production in eutrophic coastal ecosystems (Larsson \& Hagström 1982, Lessard \& Swlft 1985, Hansen 1992, Leakey et al. 1992). Such shifts from microplankton to nanoplankton and from siliceous towards non-siliceous can deeply affect the overall pelagic productivity (Officer \& Ryther 1980, Legendre \& Le Fèvre 1989) in terms of nutrient cycling, food web structure and energy flow (Michaels \& Silver 1988). Whereas diatoms generally promote transfer of energy to higher trophic levels, many of the organisms belonging to smaller size classes are more involved in the 'microbial food web' (Doering et al. 1989, Legendre \& Le Fèvre 1989), rather than contributing directly to the planktonic food chain (Azam et al. 1983). Therefore, the composition and the size structure of the phytoplankton community partly reflect the relative importance of the microbial food web for overall ecosystem production (Sieburth et al. 1978, Azam et al. 1983, Fenchel 1987. Hagström et al. 1988, Caron 1991) and should therefore be quantified.

In the studied ecosystem, the Bay of Brest (France), a macrotidal coastal ecosystem influenced by freshwater inputs and rapid exchange with adjacent ocean waters (see Del Amo et al. 1997), a doubling in the nitrate riverine supply during the last $20 \mathrm{yr}$ and a parallel decrease of the Si:DIN (silicic acid:dissolved inorganic nitrogen) ratio in coastal waters (from 2.00 to 0.33 ) have been observed (Le Pape et al. 1996). The apparent phytoplankton productivity has not shown any response yet to this increased nitrogen fertilization (Le Pape et al. 1996), but silicic acid was found to be the current potential limiting factor of diatom growth in the Bay of Brest during spring and summer (Ragueneau et al. 1994, Del Amo et al. 1997).
This study is part of a major, multi-annual, research project (Contrat de Baie), which focused on the assessment of the consequences of increasing nitrate freshwater loads on the ecological balance of the Bay of Brest. A companion paper (Del Amo et al. 1997) discusses the nutritional limitation of primary production over the entire annual cycle. In this study, we focus on changes in species composition and size distribution within the phytoplankton community over the annual cycle in relation to environmental variations. To explain the persistence of the paradoxical diatom dominance in Si-limited environments, we finally address the question of the specific functioning of the silicic acid (i.e. silicate) pump (see Dugdale et al. 1995) in well-mixed coastal ecosystems.

\section{MATERIALS AND METHODS}

Sampling strategy and analytical methods. Data collection was carried out during 30 cruises between 15 February 1993 and 21 March 1994, at Stn $R_{3}\left(48^{\circ} 20^{\prime} \mathrm{N}\right.$, $4=30^{\circ} \mathrm{W}$ ) (Fig. $i$ ), which is located in the centrai pari of the Bay of Brest and is considered to be typical of the main part of the Bay (Quéguiner 1982, Delmas \& Tréguer 1983, Ragueneau et al. 1994). Sampling frequency ranged from twice a week during spring to once a month during winter, and determination of physical (temperature, salinity), chemical (nutrients) and biological parameters (oxygen, biomass and primary production) was performed in non-replicated samples from different depths of the water column. Biomass of siliceous forms (biogenic silica or BSi) was determined for surface and bottom water samples of 500 to $1000 \mathrm{ml}$ of seawater after filtration through $0.6 \mu \mathrm{m}$ polycarbonate Nuclepore filters. Filters were dried for $24 \mathrm{~h}$ at $60^{\circ} \mathrm{C}$ and stored in closed plastic Petri dishes for further determination of BSi, according to Ragueneau \& Tréguer (1994) (precision: $5 \%$ ). Detailed sampling strategy and basic analytical methods are described in Del Amo et al. (1997).

Size fractionation. Because vertical mixing generally characterizes this system (see Del Amo et al. 1997), size fractionation was only performed on surface water samples for particulate organic carbon (POC) and nitrogen (PON), chlorophyll a (chl a), phaeopigments, BSi and primary production rates. Size fractionations of chl $a$, phaeopigments, BSi and primary production were conducted by post-screening through Nuclepore filters $(10 \mu \mathrm{m}, 2 \mu \mathrm{m}$, and $0.6 \mu \mathrm{m})$ on a 3 level Sartorius filtration device. Concentrations in unfractionated samples (Nuclepore $>0.6 \mu \mathrm{m}$ ) were also measured, and, except for the BSi, they have been reported in Del Amo et al. (1997).

For POC and PON fractionation, seawater was prefiltered through 2 or $10 \mu \mathrm{m}$ Nuclepore filters, and then 


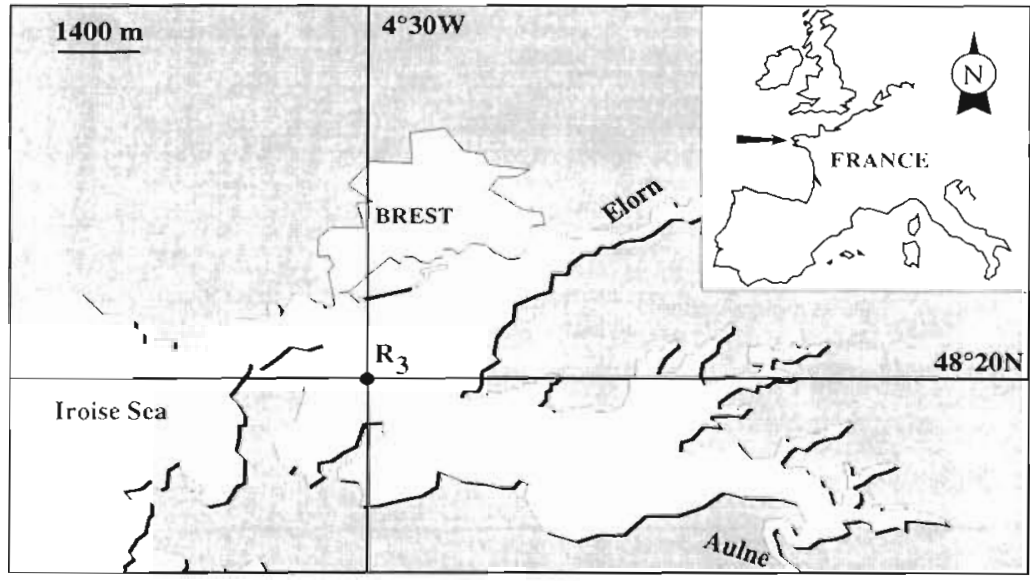

Fig. 1. Study area and location of station $\left(\mathrm{R}_{3}\right)$ sampled during 1993-1994 in the Bay of Brest, France

tration to be equal to the sum of the fractionated samples.

Plankton species identification and numeration. Samples for plankton species composition in surface and bottom waters were preserved on board with an acid Lugol's solution. Species were identified and counted by microscopic examination on an inverted microscope (Utermöhl 1931). The enumeration of microzooplankton was restricted to ciliates and identification of dinoflagellates was done only for the recognizable genera. Nanoplankton (<10 $\mu \mathrm{m}$ linear size) identification was also restricted to cryptophyceans and dinoflagellates, and, for the purpose of simplification, we will refer to them as 'nanoflagellates', i.e. the smallest non-

through Whatman GF/F filters (pore size ca $0.7 \mu \mathrm{m}$ ). Concentrations in unfractionated samples (Whatman GF/F filter) were also measured and are reported by Del Amo et al. (1997). POC and PON concentrations within each size class were then calculated from the differences between total concentration and the concentrations of the different prefiltered samples

Vacuum pressure $<0.5$ bar was used for all filtrations, as a compromise between prevention of cellular material breakdown during the filtration procedure (Banse et al. 1963, Arthur \& Rigler 1967) and extended filtration time.

The correlations between the sum of the concentrations in the 3 size classes $(0.6-2,2-10$ and $>10 \mu \mathrm{m})$ and the unfractionated samples were tested by linear regression analysis for chl a, phaeopigments (phaeo), $\mathrm{BSi}$ and primary production rates (PP). For each parameter, the sum of the fractions appeared well correlated to the total, as shown by the following equations:

$$
\begin{aligned}
& \sum \text { chl } a_{\text {size fractions }}=0.910 \text { chl } a_{\text {total }}-0.003 \\
& \mathrm{n}=30, \mathrm{R}^{2}=0.986(\alpha<0.001) \\
& \sum \text { phaeo }_{\text {stze fractions }}=0.892 \text { phaeo }_{\text {total }}-0.006 \\
& \mathrm{n}=30, \mathrm{R}^{2}=0.936(\alpha<0.001) \\
& \sum \mathrm{BSi}_{\text {size fractions }}=0.871 \mathrm{BSi}_{\text {total }}+0.198 \\
& \mathrm{n}=19, \mathrm{R}^{2}=0.938(\alpha<0.001) \\
& \sum \mathrm{PP}_{\text {size fractions }}=0.923 \mathrm{PP}_{\text {total }}+0.308 \\
& \mathrm{n}=30, \mathrm{R}^{2}=0.855(\alpha<0.001)
\end{aligned}
$$

On average, for each parameter, the sum of the different size-fractionated samples was close to $90 \%$ of the total unfractionated samples, but on some occasions the sum of the size-fractionated samples was higher than the value for the total sample. In this study, in order to derive percent contributions of each size fraction to the total, we have assumed the total concen- siliceous cells. 'Microplankton' will encompass the larger organisms, i.e. all diatoms and dinoflagellates $>10 \mu \mathrm{m}$. Some diatom cells $<10 \mu \mathrm{m}$ can be found in the Bay of Brest; however, they are seldom found as isolated organisms but rather form large colonies of individuals, like Skeletonema costatum and Chaetoceros sociale, which are retained on the $10 \mu \mathrm{m}$ filters. Counts varied from 200 to 1600 cells per sample, leading to an accuracy range of 5 to $16 \%$ (i.e. percent of total) (Lund et al. 1958).

\section{RESULTS}

Based on biomass and primary production changes (Fig. 2), Del Amo et al. (1997) divided the annual cycle of the Bay of Brest into 4 periods: Period I, the spring transition period (15 February to 1 April 1993); Period II, the spring bloom period (1 April to 18 May 1993); Period III, the secondary blooms period (18 May to 7 October 1993); and Period IV, the fall/winter period ( 7 October 1993 to 17 February 1994). Within the annual cycle, BSi concentrations (Figs. $2 \& 3$ ) and the phytoplankton succession (Figs. $4 \& 5$ ) reflected the above partitioning particularly well, as difterent community structures characterized each phase (see below).

\section{The $>10 \mu \mathrm{m}$ size class}

During the 1993-1994 annual cycle, the seasonal variations of biomass and primary production (Figs. 2 \& 3) were mainly caused by the $>10 \mu \mathrm{m}$ size class. The latter was dominated by diatoms (see below) all year round. This size class accounted for 23 to $46 \%(0.1$ to $0.2 \mathrm{\mu g}^{-1}$ ) of total chl a (Fig. 2a) during the fall/winter 

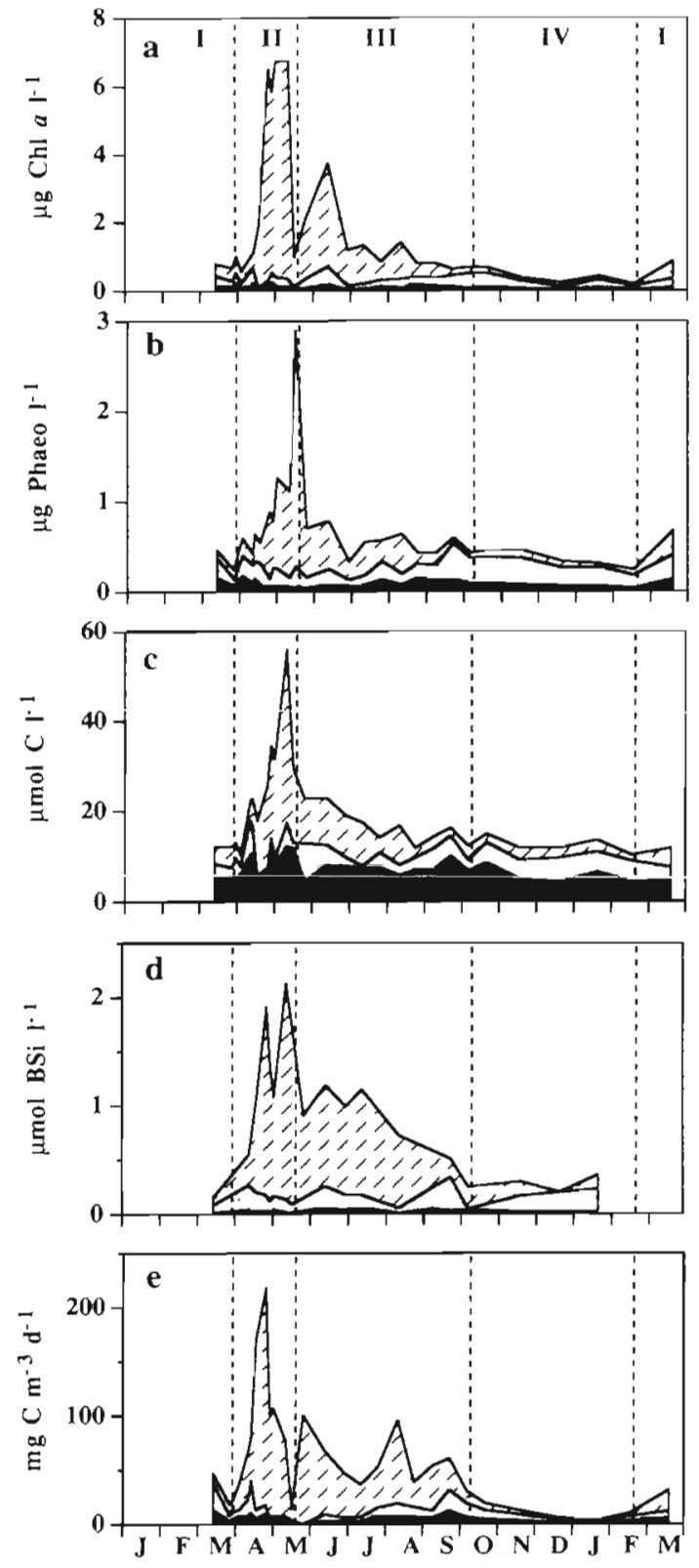

- $0.6-2 \mu \mathrm{m} \quad \square \quad 2-10 \mu \mathrm{m} \quad \square>10 \mu \mathrm{m}$

Fig. 2. Biomass and primary production in slze-fractionated samples in surface waters of the Bay of Brest during the 1993-1994 annual cycle (Stn $\mathrm{R}_{3}$ ). (a) Chl a ( $\left.\mathrm{g} \mathrm{l}^{-1}\right)_{\text {i }}$ (b) phaeopigments $\left(\mu \mathrm{g} \mathrm{l}^{-1}\right)_{i}(\mathrm{c})$ POC $\left(\mu \mathrm{mol} \mathrm{l}{ }^{-1}\right)_{i}(\mathrm{~d}) \mathrm{BSi}\left(\mu \mathrm{mol} \mathrm{l^{-1 }}\right)_{i}(\mathrm{e})$ primary production ( $\mathrm{mg} \mathrm{C} \mathrm{m} \mathrm{m}^{-3} \mathrm{~d}^{-1}$ ). Periods: $\mathrm{I}$, spring transition;

II, spring bloom; III, secondary blooms; IV, fall/winter

period, whereas it accounted for up to $91-95 \%$ (5.3 to $6.4 \mathrm{\mu g} \mathrm{l}^{-1}$ ) during the spring bloom in April-May. During the secondary blooms period, there was a somewhat regular trend of decreasing contribution of the $>10 \mu \mathrm{m}$ size class, which represented respectively $81 \%\left(3.0 \mu \mathrm{g} \mathrm{l}^{-1}\right), 84 \%\left(1.1 \mu \mathrm{g} \mathrm{l}^{-1}\right), 75 \%\left(1.1 \mu \mathrm{g} \mathrm{l}^{-1}\right)$, and
$54 \%\left(0.4 \mu \mathrm{g} \mathrm{l}^{-1}\right)$ of the total at each successive chl a maximum

The maximum contribution of phaeopigments from the $>10 \mu \mathrm{m}$ size class, accounting for as much as $90 \%$ $\left(2.6 \mu \mathrm{g} \mathrm{l}^{1}\right)$ of the total (Fig. 2b), was reached at the phaeopigment maximum on 18 May when the bloom collapsed. Although phaeopigments are known to be overestimated by the analytical method used for this study (Turner ${ }^{\text {T.M }}$ fluorometry), they can represent up to $50 \%$ of total pigments in coastal waters (Longhurst et al. 1995). During the secondary blooms period, the $>10 \mu \mathrm{m}$ size class showed a decreasing trend, with values ranging from 0.2 to $0.5 \mu \mathrm{g} \mathrm{I}^{-1}$ ( 40 to $70 \%$ of the total) until mid-August, whereas for the rest of the year including the fall/winter period, values were very low $\left(0.1 \mu \mathrm{g} \mathrm{l}^{-1}\right)$

Because POC and PON concentrations exhibited a similar pattern within the annual cycle (Del Amo et al. 1997), only the annual progression of POC within the size classes is shown in Fig. 2c. POC and PON maximums of the $>10 \mu \mathrm{m}$ size class were reached simultaneously with the spring bloom chl a maximum (Fig. 2a), as weil as with BSi maximum (Fig. Zaj). Át thai time, the $>10 \mu \mathrm{m}$ size class accounted for $69 \%$ $\left(38.3 \mu \mathrm{mol} \mathrm{C} \mathrm{l}^{-1}\right)$ and $61 \%\left(3.5 \mu \mathrm{mol} \mathrm{N} \mathrm{^{-1 }}\right)$ of the total concentrations of POC and PON respectively. Two distinct peaks of BSi concentrations were observed during the spring bloom $\left(1.79 \mu \mathrm{mol} \mathrm{l}^{-1}\right.$ on 27 April and $1.99 \mathrm{\mu mol} \mathrm{H}^{-1}$ on 13 May; Fig. 2d). Both of them were mainly due to diatoms $>10 \mu \mathrm{m}$ (this size class accounted respectively for 91 and $94 \%$ of the total BSi concentration), but the diatom populations of each peak were dominated by a different species (see below). Although the water column was well mixed during the year, it is noteworthy that at each decline of the diatom blooms (late April mid-May and JuneJuly), total BSi concentrations in bottom waters were slightly higher than surface concentrations (Fig. 3). During the secondary blooms period, POC, PON and BSi concentrations of the $>10 \mu \mathrm{m}$ size class remained. relatively high until mid-August (ranges: 3.1 to 10.3 $\mu \mathrm{mol} \mathrm{C}{ }^{-1}, 0.6$ to $1.4 \mu \mathrm{mol} \mathrm{N} \mathrm{l}^{-1}$ and 0.7 to $1.0 \mu \mathrm{mol} \mathrm{Si}$ $\left.\mathrm{l}^{-1}\right)$, accounting for 22 to 55,36 to 62 and 78 to $92 \%$, respectively, of the totals; afterwards, values decreased rapidly and the contribution of this size class remained minor during the rest of the year.

On an annual scale, $73 \%$ of the integrated annual primary production at the surface was achieved by the $>10 \mu \mathrm{m}$ size class, and that fraction was responsible for most of the major seasonal variations of primary production (Fig. 2e). Four successive peaks of total primary production rates were observed during the 19931994 annual cycle (Del Amo et al. 1997). The $>10 \mu \mathrm{m}$ size class accounted for $92 \%\left(200.4 \mathrm{mg} \mathrm{C} \mathrm{m}^{-3} \mathrm{~d}^{-1}\right)$ of the total during the spring bloom peak of 27 April and 


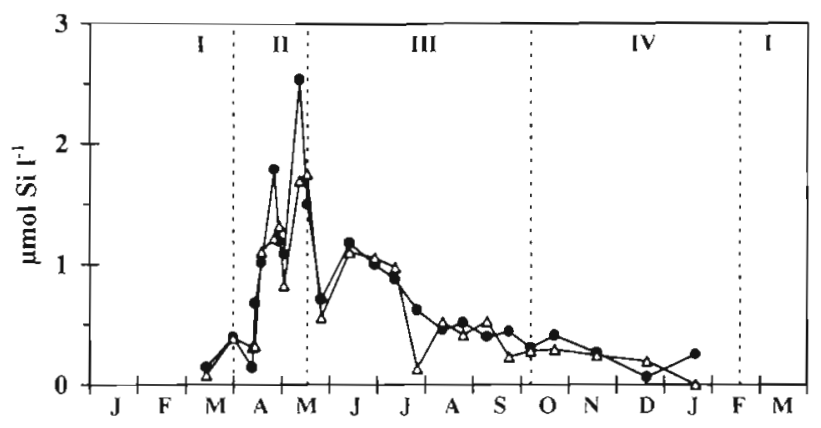

Fig. 3. Biogenic silica (BSi) concentrations in surface $(\bullet)$ and bottom $(\triangle)$ waters of the Bay of Brest during the 1993-1994 annual cycle ( $\operatorname{Stn} \mathrm{R}_{3}$ ). Periods as in Fig. 2

$83 \%\left(100.8 \mathrm{mg} \mathrm{C} \mathrm{m} \mathrm{m}^{-3} \mathrm{~d}^{-1}\right)$ and $80 \%\left(76.8 \mathrm{mg} \mathrm{C} \mathrm{m}^{-3} \mathrm{~d}^{-1}\right)$ of the totals, respectively, during the first 2 secondary blooms. However, the $>10 \mu \mathrm{m}$ size class did not dominate the last secondary bloom in September, when its contribution to the total was only $48 \%$ (28.8 $\mathrm{mg} \mathrm{C} \mathrm{m}^{-3} \mathrm{~d}^{-1}$ ) and cryptophyceans dominated over diatoms.

\section{The $2-10 \mu \mathrm{m}$ size class}

The $2-10 \mu \mathrm{m}$ size class showed relatively low concentrations in each biomass parameter (Fig. 2). Throughout the productive period, chl $a$, phaeopigment, $\mathrm{POC}$ and $\mathrm{BSi}$ concentrations remained $\leq 0.6 \mu \mathrm{g} \mathrm{l}^{-1}, 0.4 \mu \mathrm{g} \mathrm{l}^{-1}, 8 \mu \mathrm{mol} \mathrm{C} \mathrm{^{-1 }}$ and $0.3 \mu \mathrm{mol} \mathrm{Si} \mathrm{l^{-1 }}$ respectively. Some distinct peaks of chl a and POC concentrations (Fig. 2a, c) were however observed during the spring bloom, when first cryptophyceans and then nanodinoflagellates developed intensively (Fig. 6). During the secondary blooms period, the 2-10 $\mathrm{m}$ size class showed a regular increase in its contribution to the total biomass, i.e. an inverse progression as compared to the $>10 \mu \mathrm{m}$ size class: chl a concentrations increased from $0.1 \mathrm{~kg} \mathrm{l}^{-1}$ (9\% of the total) in late June up to $0.5 \mathrm{\mu g} \mathrm{I}^{-1}(67 \%)$ in early October, and phaeopigment concentrations (Fig. 2b) increased from $0.1 \mu \mathrm{g} \mathrm{l}^{-1}(24 \%)$ in late June to $0.4 \mathrm{\mu g} \mathrm{l}^{-1}$ $(68 \%)$ in late September. It is noteworthy that during the fall/winter period, most of the phaeopigments $(62$ to $68 \%$ of the total) were found in that size class. Small variations characterized the BSi concentrations of the 2-10 $\mu \mathrm{m}$ size class throughout the year and the contribution of this size class to total BSi was generally $<17 \%$ during the productive period; the maximum BSi con-

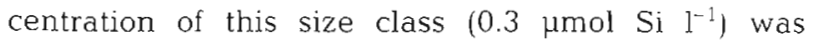
reached in September, when it accounted for $60 \%$ of the total (Fig. 2d).

As for biomass, primary production (Fig. 2e) within the $2-10 \mu \mathrm{m}$ size class was relatively low (range 1.2 to
$30 \mathrm{mg} \mathrm{C} \mathrm{m} \mathrm{m}^{-3} \mathrm{~d}^{-1}$ ) and accounted for only $17 \%$ of the total integrated annual surface value. The highest values were measured during the spring transition (25.2 $\mathrm{mg} \mathrm{C} \mathrm{m} \mathrm{m}^{-3} \mathrm{~d}^{-1}, 53 \%$ of the total), as well as during the spring bloom, when this size class accounted for $38 \%$ of the total primary production $\left(30 \mathrm{mg} \mathrm{C} \mathrm{m}^{-3} \mathrm{~d}^{-1}\right)$; afterwards, its contribution dropped down to $6 \%$. During the secondary blooms period, successive peaks of increasing amplitude occurred, and we observed an increasing trend similar to that of biomass, up to $33 \%$ (20.4 $\mathrm{mg} \mathrm{C} \mathrm{m}^{-3} \mathrm{~d}^{-1}$ ) in late September.

\section{The $0.6-2 \mu \mathrm{m}$ size class}

The picoplankton showed no or little seasonal variations in terms of chl a, phaeopigment, BSi and primary production over the annual cycle (Fig. 2), with respective concentrations of $\leq 0.3 \mu \mathrm{gl}^{-1}, 0.2 \mu \mathrm{g} \mathrm{l}^{-1}, 0.1 \mu \mathrm{mol} \mathrm{Si}$ $\mathrm{l}^{-1}$ and $13.2 \mathrm{mg} \mathrm{C} \mathrm{m} \mathrm{m}^{-3} \mathrm{~d}^{-1}$ throughout the year. On an annual basis, the primary production of the 0.6-2 $\mu \mathrm{m}$ size class (Fig. 2e) represented only $10 \%$ of the integrated surface rate. The seasonal progression of primary production rates exhibited a pattern quite similar to that of the $2-10 \mu \mathrm{m}$ size class, with increases occurring during the spring transition and the spring bloom (range: 2.4 to $13.2 \mathrm{mg} \mathrm{C} \mathrm{m} \mathrm{m}^{-3}$ ), and a gradual increase from June to late September from 1.2 to $12 \mathrm{mg} \mathrm{C} \mathrm{m}{ }^{-3} \mathrm{~d}^{-1}$, when the $0.6-2 \mu \mathrm{m}$ size class contributed up to $20 \%$ of the total. The high POC content within the $0.6-2 \mu \mathrm{m}$ size class (range of concentrations: 4.3 to $13.0 \mu \mathrm{mol} \mathrm{C} \mathrm{l}{ }^{-1}$; Fig. 2C), as compared to the low chl a concentrations $(\mathrm{C}: \mathrm{chl}$ a ratios $>463$ during the productive period), suggests either an important contribution of heterotrophs (probably linked with bacterial growth) or that most of this POC was detrital. During this period, $\mathrm{C}: \mathrm{N}$ molar ratios in this size class ranged from 8 to 37 , and phaeopigmentichl a ratios ranged from 0.2 to 2.5 , with higher values when blooms of the $>10 \mu \mathrm{m}$ size fraction died down, suggesting that the 0.6-2 $\mu \mathrm{m}$ size fraction contained fragments of dead cells and detrital material. It is known that size fractionation can result in overestimation of picoplankton due to retention of cellular material from broken or damaged larger cells during the filtration procedure (e.g. Lignell 1992, Fahnenstiel et al. 1994); therefore, some contamination of the $0.6-2 \mu \mathrm{m}$ size class by POC and PON from cellular fragments of larger cells is possible.

\section{Species composition}

Counts on surface and bottom samples were close to each other throughout the year; hence, the results herein are those for surface samples only. 


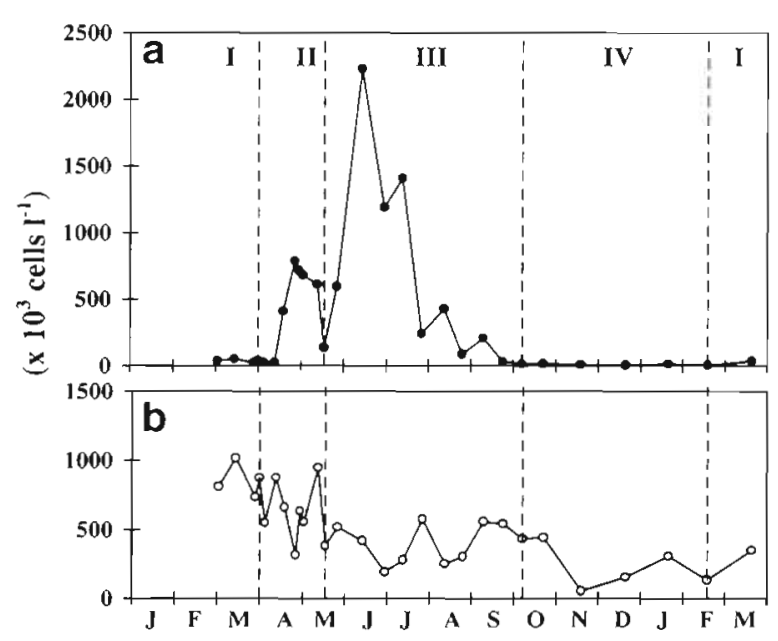

Fig. 4. (a) Microplankton and (b) nanoflagellate cell concentrations in surface waters of the Bay of Brest during the 1993-1994 annual cycle (Stn $\left.R_{3}\right)$. Periods as in $\Gamma$ ig. 2

Nanoflagellates exhibited a narrow range of varia-

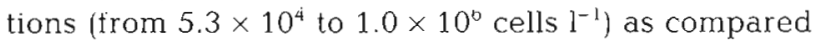
to the major changes observed in microplankton cell numbers (range: $3.1 \times 10^{3}$ to $2.2 \times 10^{6}$ cells $1^{-1}$ ) (Fig. 4). On an annual scale, the striking feature within the microplankton was the year-round dominance of diatoms over dinoflagellates (Fig 5). Dinoflagellates were mainly observed during the secondary blooms period but, even at that time, they did not exceed $5.1 \times$ $10^{4}$ cells $\mathrm{l}^{-1}$, i.e. 2 orders of magnitude lower than diatoms.

Period IV: fall/winter. This period was characterized by low cell numbers of both diatoms $\left(<1.1 \times 10^{4}\right.$ cells $\left.\mathrm{I}^{-1}\right)$ and dinoflagellates $\left(<8.0 \times 10^{3}\right.$ cells $\left.\mathrm{I}^{-1}\right)$. The diatom population was mainly composed of small chains or isolated cells of Thalassionema nitzschoides, Pseudonitzschia spp. and Thalassiosira spp. During that period, nanoflagellates did not exceed $4.5 \times 10^{5} \mathrm{cells}^{-1}$ and occasional increases were mainly related to cryptophyceans (Fig. 6)

Period I: spring transition. Beginning in mid-February, a slight increase of the microplankton was observed with the development of Skeletonema costatum, reaching up to $5.0 \times 10^{4}$ cells $\mathrm{l}^{-1}(68 \%$ of total microplankton on 15 March 1993) (Fig. 5a). Other diatoms present at that time were Thalassiosira cf. fallax and $T$. cf. rotula. Small (10 to $20 \mu \mathrm{m}$ ) dinoflagellates like Scrippsiella trochoidea, Cachonina niei, Heterocapsa triquetra and Minuscula bipes gained importance in early spring; however, a large proportion of unidentified dinoflagellates, more often represented by single or few individuals in the cell counts, was observed (Fig. 5b). Within the nanoflagellate group, an a

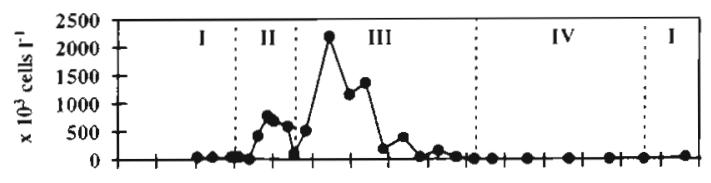

Chaetoceros spp.

Leptocylindrus spp.

Rhizosolenia spp.

Skeletonema spp.

Thalassiosira spp

n.i. diatoms
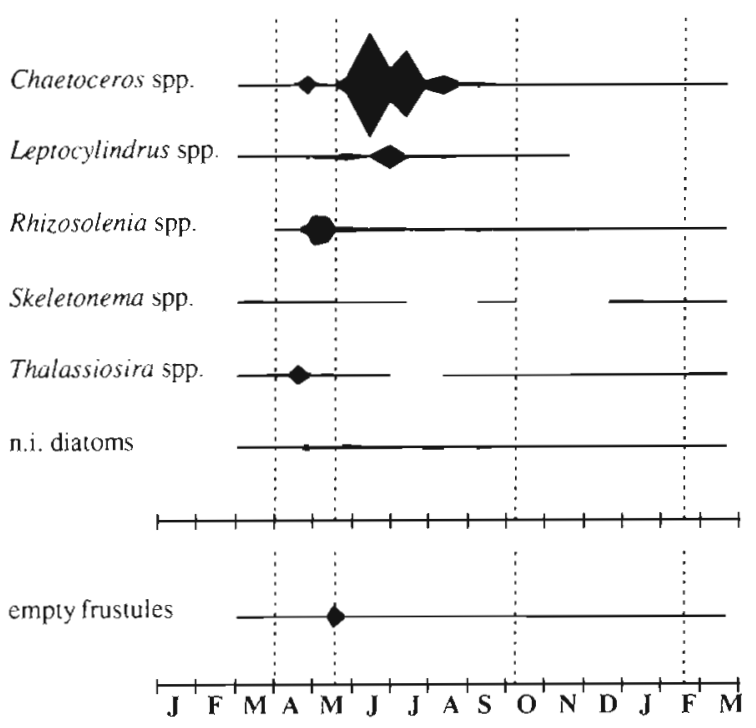

b

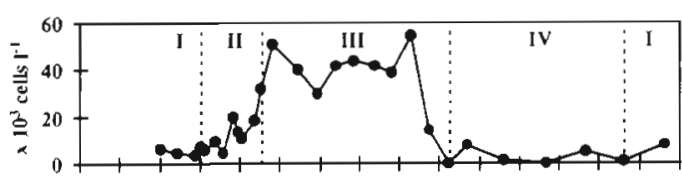

Ceratium spp.

Dinophysis spp

Gymnodinium of. nagasakiense

Gymnodinium spp

Gyrodinium spp.

Goniaulax spp.

Prorocentrum spp

Protoperidinium spp.

small dinoflagellates

n.i. dinoflagcllates

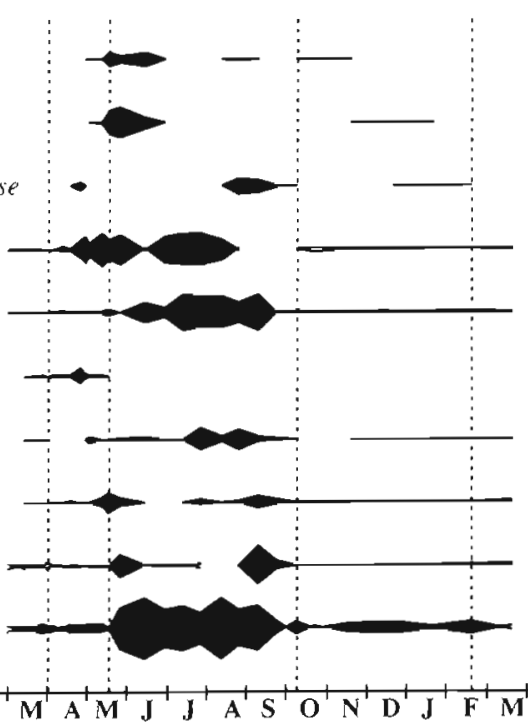

Fig. 5. Cell concentrations of the major phytoplankton groups observed within the microplankton $(>10 \mu \mathrm{m})$ in surface waters of the Bay of Brest during the 1993-1994 annual cycle (Stn $\mathrm{R}_{3}$ ). (a) Diatoms; (b) dinoflagellates. 'Small dinoflagellates'. Scrippsiella trochoidea, Cachonina niei, Heterocapsa triquetra, and Minuscula bipes. n.i.. not identified. Periods as in Fig. 2 


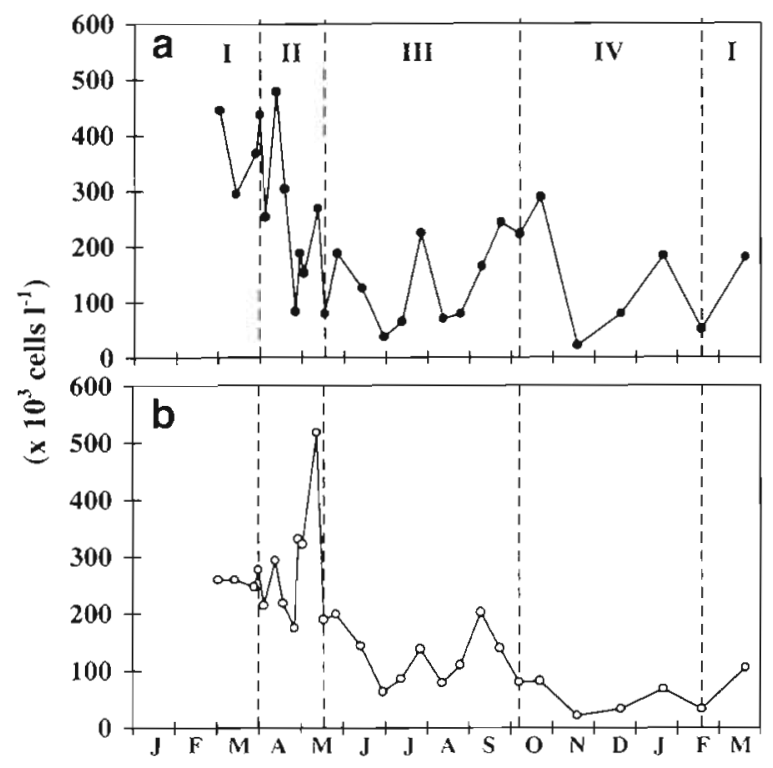

Fig. 6. Cell concentrations of the major groups observed within the nanoflagellates in surface waters of the Bay of Brest during the 1993-1994 annual cycle $\left(\operatorname{Stn} \mathrm{R}_{3}\right)$. (a) Cryptophyceans; (b) $<10 \mu \mathrm{m}$ dinoflagellates. Periods as in Fig. 2

increase of small unidentified species occurred simultaneously with a decrease of cryptophyceans, while nanodinoflagellates showed little variations in cell numbers (Fig. 6).

Period II: spring bloom. A broad peak of microplankton from mid-April until mid-May $\left(7.8 \times 10^{5}\right.$ to $6.1 \times 10^{5}$ cells 1 $^{-1}$; Fig. 4) was observed simultaneously with maximums in $>10 \mu \mathrm{m}$ size class primary production and biomass (chl $a$ and BSi; Fig. 2a, d). This peak was due to 2 diatom-dominated populations (Fig 5a): during the early spring bloom period, the chain-forming Thalassiosira cf. fallax accounted for as much as $86 \%$ of the total microplankton number and was accompanied by a mixed population of Chaetoceros spp. (C. cf. debile, C cf. curvisetum, C. cf. affine, C. sociale, $C$. cf. protuberans). Afterwards, a mixed population of Rhizosolenia spp. (mainly $R$. delicatula and $R$. fragilissima) dominated, accounting for up to $85 \%\left(5.8 \times 10^{5}\right.$ cells $\mathrm{l}^{-1}$ ) of the total microplankton number. After this peak, microplankton cell number dropped to $<1.4 \times$ $10^{5}$ cells $1^{-1}$ on 18 May and, accordingly, a large number of empty frustules $\left(4.2 \times 10^{5}\right.$ cells $\left.1^{-1}\right)$ was observed.

The major increase in dinoflagellate numbers occurred from mid-April and was concomitant with the development of the Rhizosolenia population, although dinoflagellates did not collapse on 18 May as did the diatom community (Fig. 5a, b). The dinoflagellate population was composed of a variety of species belonging to the genera Gonyaulax, Gymnodinium, Gyrodinium, and Protoperidinium as well as the small dinoflagellates of the spring transition. The collapse of the diatom bloom on 18 May was also characterized by the emergence of toxic species like Gymnodinium cf. nagasakiense and Dinophysis spp.

During the spring bloom, nanoflagellate development progression (Fig. 4) was also characterized by 2 successive peaks. The first one, at the beginning of the period, was tightly coupled to increases in both $2-10 \mu \mathrm{m}$ size class primary production and chl $a_{1}$ and was dominated by cryptophyceans (Fig. 6). However, these forms had exhibited a dramatic decrease by late April (from $4.8 \times 10^{5}$ to $8.2 \times 10^{4}$ cells $1^{-1}$ ), and at the end of the spring bloom, a second nanoflagellate development was essentially dominated by nanodinoflagellates. It is noteworthy that this increase of the $<10 \mu \mathrm{m}$ dinoflagellates matched the development of the larger dinoflagellates of the microplankton mentioned before. Ciliates started to develop during the spring bloom and their number ranged between $1.8 \times 10^{3}$ and

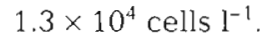

Period III: secondary blooms. The first secondary bloom was characterized by the most striking increase of microplankton numbers (up to $2.2 \times 10^{6}$ cells ${ }^{-1}$; Fig. 4) although increases in chl $a$ and BSi concentrations as well as in primary production rates in the $>10 \mu \mathrm{m}$ size class were only moderate, i.e. $3.0 \mathrm{\mu g}^{-1}, 1.0 \mu \mathrm{mol} \mathrm{Si} \mathrm{l}{ }^{-1}$ and $8.4 \mathrm{mg} \mathrm{C} \mathrm{m}^{-3} \mathrm{~d}^{-1}$, respectively (Figs. 2 \& 3). The reason for the weaker variation in biomass and production parameters as compared to cell numbers has to be related to differences in the species composition of the diatom population (Fig. 5a). The secondary blooms were dominated by Chaetoceros sociale, which accounted for up to $98 \%$ of the Chaetoceros spp. cell counts during the first microplankton peak. As already mentioned, individuals of this species are $<10 \mu \mathrm{m}$ in size but they are included in the microplankton because they are organized in chains. Rhizosolenia spp., as well as other species of the Chaetoceros sub-genus Hyalochaete, forming long and twisted chains of small cells, were also present together with Leptocylindrus spp. during the successive secondary blooms.

Dinoflagellates reached their maximum $\left(5.1 \times 10^{4}\right.$ cells $\mathrm{l}^{-1}$ ) at the beginning of the secondary blooms period and remained relatively abundant (range: 3.0 to $5.1 \times 10^{4}$ cells $1^{-1}$ ) until mid-September (Fig. 5b), but without ever dominating over diatoms. Prorocentrum micans, Gymnodinium spp., Gyrodinium spp. and unidentified dinoflagellate cell types were the most abundant, but smaller dinoflagellates again developed at the end of this period. It should be noted that maximum cell concentration of Dinophysis spp. (up to $9.6 \times$ $10^{3}$ cells $\mathrm{l}^{-1}$ ) occurred simultaneously with that of the prymnesiophyte Phaeocystis pouchetii $\left(5.1 \times 10^{4}\right.$ cells $\left.\mathrm{l}^{-1}\right)$ at the beginning of the secondary blooms period. 
Euglena spp. were also observed with increasing numbers from mid-Juiy $\left(3.5 \times 10^{3}\right.$ cells $\left.1^{-1}\right)$ to early September $\left(1.9 \times 10^{4}\right.$ cells $\left.l^{-1}\right)$.

Three moderate peaks of nanoflagellates $\left(<5.8 \times 10^{5}\right.$ cells $\mathrm{l}^{-1}$ ) characterized the secondary blooms period (Fig. 4), a pattern close to that of the chl a and primary production of the $2-10 \mu \mathrm{m}$ size class. The last increases in 2-10 $\mu \mathrm{m}$ size class chl a and primary production were mainly attributable to cryptophyceans (Fig. 6). A close relationship between nanoflagellates and ciliates was observed during the secondary blooms period: each increase in nanoflagellate concentration occurring during the secondary blooms period was paralleled by an increase in ciliate numbers, suggesting that nanoflagellates were controlled by ciliates during the secondary blooms period.

\section{DISCUSSION}

\section{Phytoplankton community structure}

\section{Shift from microplankton to nanoplankton?}

The overwhelming contribution of the $>10 \mu \mathrm{m}$ size class to chl $a$, POC and BSi biomass and the primary production throughout the productive period (from early April to early October) is a major feature of the seasonal plankton cycle of the Bay of Brest (Fig. 7, Table 1). The seasonal increases in plankton biomass and primary production are mainly associated with changes in the respective concentrations of the $>10 \mu \mathrm{m}$ size class. On an annual basis, the $>10 \mu \mathrm{m}$ size class accounted both for $73 \%$ of the time-weighted average chl $a$ and of the time-weighted average primary pro- duction in surface waters. Contrary to the situation found in other $\mathrm{N}$-enriched coastal systems, like the Gulf of Mexico (Nelson \& Dortch 1996), the Northern Adriatic Sea (Revelante \& Gilmartin 1976, Malej et al. 1995), the Chesapeake Bay (Fisher et al. 1992, Sellner 1987), or the Otsuchi Bay (Tsuda et al. 1994), where summer phytoplankton is dominated by nanoflagellates, most of the Bay of Brest summer phytoplankton belongs to the microplankton size class. However, due to the possibility of developments of cryptophyceans, the last secondary bloom at the end of the productive period may be characterized by a substantial contribution of the $2-10 \mu \mathrm{m}$ size class to total primary production and to chl $a$. This situation is comparable to that of the Gulf of Trieste where a late summer peak of nanophytoplankton is usually observed (Malej et al. 1995). As expected due to their chain-forming characteristic, diatom contribution in the $2-10 \mu \mathrm{m}$ size class is low (only $21 \%$ of the annual time-averaged BSi concentration was found in that fraction).

Nevertheless, an increasing contribution of the 2-10 $\mathrm{m}$ size class from May to September (Fig. 7) occurs in the Bay of Brest as $\mathrm{N}$ becomes the major Iımiting nutrient (Del Amo et al. 1997). Therefore, this increase does not seem to represent a response of the community structure to the high-nitrate loads to the Bay by freshwater inputs. The nanoflagellate bloom would rather reflect their better adaptation to low nutrient conditions (Egge \& Aksnes 1992). A better adaptation to low irradiances is also suggested by the predominant contribution of the $2-10 \mu \mathrm{m}$ size class to total biomass and primary production during the periods when primary production is primarily limited by light (Quéguiner \& Tréguer 1984, Del Amo et al. 1997), i.e. the fall/winter period and the spring transition.

Table 1. Summary of the main features of each seasonal period. Chl a concentrations and primary production rates are timeweighted averaged values for each perod (ranges in parentheses). Small dinoflagellates: Minuscula bipes, Scrippsiella trochoidea, Cachonina niei and Heterocapsa triquetra

\begin{tabular}{|c|c|c|c|c|}
\hline & IV: fall/winter & I: spring transition & II: spring bloom & III: secondary blooms \\
\hline Nutrient characteristic & $N$ excess & $N$ excess & Si limitation & Si, $P$ and $N$ imitation \\
\hline Chl a $\left(\mu \mathrm{gl}^{-1}\right)$ & $\begin{array}{c}0.39 \\
(0.28-0.47)\end{array}$ & $\begin{array}{c}0.87 \\
(0.61-1.14)\end{array}$ & $\begin{array}{c}4.08 \\
(0.65-7.74)\end{array}$ & $\begin{array}{c}1.52 \\
(0.66-3.47)\end{array}$ \\
\hline $\begin{array}{l}\text { Primary production } \\
\left(\mathrm{mg} \mathrm{C} \mathrm{m}^{-3} \mathrm{~d}^{-1}\right)\end{array}$ & $\begin{array}{c}13.2 \\
(6.6-25.3)\end{array}$ & $\begin{array}{c}38.3 \\
(28.0-45.1)\end{array}$ & $\begin{array}{c}93.6 \\
(9.8-190.8)\end{array}$ & $\begin{array}{c}63.1 \\
(23.4-126.5)\end{array}$ \\
\hline $\begin{array}{l}\text { Dominant diatom } \\
\text { species }\end{array}$ & Mixed & $\begin{array}{l}\text { S. costatum, } \\
\text { Thalassiosira spp. }\end{array}$ & $\begin{array}{l}\text { Thalassiosira spp., } \\
\text { Rhizosolenia spp. }\end{array}$ & $\begin{array}{l}\text { Chaetoceros spp., } \\
\text { Leptocylindrus spp. }\end{array}$ \\
\hline $\begin{array}{l}\text { Dominant dinoflagellate } \\
\text { species }\end{array}$ & Mixed & Small dinoflagellates & $\begin{array}{l}\text { Gymnodinium spp., } \\
\text { small dinoflagellates }\end{array}$ & $\begin{array}{l}\text { Gymnodinium spp., } \\
\text { Gyrodinium spp., } \\
\text { Dinophysis spp. }(22 \%)\end{array}$ \\
\hline $\begin{array}{l}\text { Dominant nanoflagellate } \\
\text { group }\end{array}$ & Cryptophyceans & Cryptophyceans & $\begin{array}{l}\text { April: cryptophyceans } \\
\text { May: dinoflagellates }\end{array}$ & Mixed \\
\hline
\end{tabular}


fall/winter

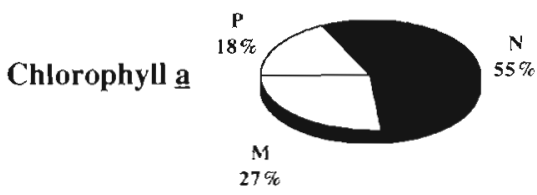

\section{Primary} production

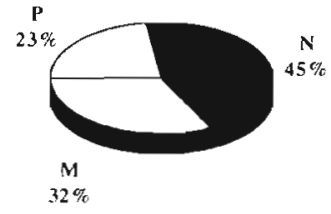

spring transition
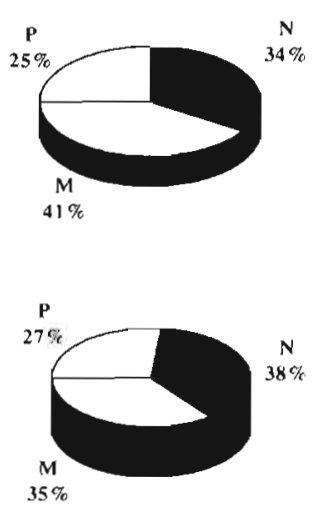

spring bloom
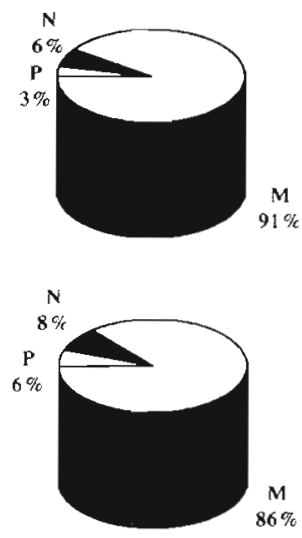

secondary blooms
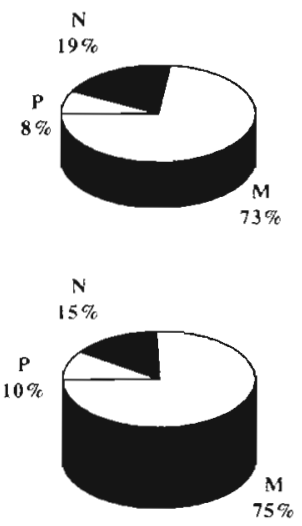

Fig. 7. Contribution of each size class (M: $>10 \mu \mathrm{m} ; \mathrm{N}: 2-10 \mu \mathrm{m} ; \mathrm{P} \cdot 0.6-2 \mu \mathrm{m}$ ) to the time-weighted averaged chl a concentration and to the integrated primary production rate during each period of the year. Pie height is proportional to the respective averaged concentration or rate

Furthermore, biological activity during those periods and during the last bloom in September is especially restricted to the surface layer.

\section{Shift from siliceous to non-siliceous species?}

A second striking feature is the dominance of diatoms as major components of primary producers within the Bay of Brest pelagic community during the spring bloom as well as during the successive secondary blooms (Table 1). Diatoms are essentially found in the largest size class, which accounted for $74 \%$ of the time-weighted average BSi concentration.

Dinoflagellates and nanoflagellates develop in summer, which is a situation similar to those found in other $\mathrm{N}$-enriched coastal systems, such as the Gulf of Mexico (Nelson \& Dortch 1996), the Adriatic Sea (Revelante \& Gilmartin 1976), the Chesapeake Bay (Fisher et al. 1992), the San Francisco Bay (Cloern 1996), or the Otsuchi Bay (Tsuda et al. 1994). The striking difference between the Bay of Brest and the above ecosystems is that summer flagellates are never dominant. Such a spring and summer diatom dominance is a common feature of nearshore well-mixed waters of the western English Channel (Grall \& Jacques 1964, MartinJézéquel 1983, Wafar et al. 1983, Ragueneau et al. 1996). However, the dinoflagellate development observed during the decline of the spring diatom bloom and its relatively long duration in summer (from early June to mid-September 1993) seem to be a new phenomenon in the Bay when compared with previous studies (Quéguiner \& Tréguer 1984).

However, although no shift from siliceous to nonsiliceous phytoplankton has been observed, the long term increase of anthropogenic $N$ inputs and the decline of the Si:DIN ratios (Le Pape et al. 1996) have led to consistent exhaustion of silicic acid by early spring followed by a period of low silicic acid levels during the secondary blooms period (Del Amo et al 1997). Si limitation of the diatom-dominated spring bloom could have triggered the shift from the Thalassiosira spp. population to the Rhizosolenia spp. community; it might also have controlled the collapse of the entire diatom population by early May while dinoflagellates (< and >10 $\mu \mathrm{m}$ ) kept growing. In the Gulf of Mexico in spring, Nelson \& Dortch (1996) observed systematic changes in response to Si limitation within the diatom assemblage, with $\mathrm{Si}$ limitation favoring species with a high affinity for silicic acid over those less adapted to silicic acid-depleted habitats.

In spite of the diatom dominance, the emergence of some undesirable $>10 \mu \mathrm{m}$ flagellates (Phaeocystis pouchetii colonies, Dinophysis spp. and Gymnodinium cf. nagasakiense) was observed during the 1993-1994 annual cycle. The emergence of $P$ pouchetii had never been observed before in the Bay of Brest, but it had already been reported as a common phenomenon in the aftermath of a diatom bloom due to nutrient depletion (van Bennekom et al. 1975, Egge \& Aksnes 1992). In contrast, Delmas et al. (1992) have explained the occurrence of Dinophysis spp. in nearshore waters of the French Atlantic coast as a result of mass transport from offshore waters. Although no data is presently available to demonstrate whether relatively dense populations of $P$. pouchetii (up to $5.1 \times 10^{4}$ cells l$^{-1}$ ) and Dinophysis spp. (up to $9.6 \times 10^{3}$ cells ${ }^{-1}$ ) in the Bay of Brest waters result from active growth, from mass transport, or from both, it is interesting to note that those species were present in the adjacent oceanic 
waters earlier within the season in cell numbers up to $4.7 \times 10^{4}$ and $2.4 \times 10^{4}$ cells l$^{-1}$, respectively.

Summer conditions prevailing in macrotidal ecosystems, i.e. the Bay of Brest and the western English Channel, may prevent a massive increase of flagellates due to high vertical mixing. As opposed to other $\mathrm{N}$ enriched ecosystems, most of the summer period in the Bay of Brest is characterized by nitrate-rich waters due to the severe imbalance of $\mathrm{Si}$ and $\mathrm{N}$ (low Si:DIN ratio) in freshwater loads (Table 2; Del Amo et al. 1997), so that the successive summer diatom developments can only occur as soon as silicic acid is again available. However, freshwater and therefore $\mathrm{Si}$ inputs from rivers in summer are very weak (Table 2 ; Del Amo et al. 1997) and therefore Si must originate from other sources such as recycling. Furthermore, diatom production during summer is particularly important, and $\mathrm{Si}$ concentrations, although potentially limiting because of the high diatom requirement, increased during this period, while DIN concentrations simultaneously decreased (Del Amo et al. 1997).

\section{Silicic acid in shallow well-mixed ecosystems}

The relatively weak development of summer dinoflagellates as compared to diatoms could be in part explained by the high vertical mixing of the water column in the Bay of Brest. However, it is important to examine the reasons why the phytoplankton cycle here is so different from other coastal systems that do not allow summer diatoms to dominate over flagellates: how can summer diatom growth be so important in the Bay of Brest after the drastic Si limitation in spring?

The year-round dominance of diatoms cannot be supported without Si availability and should be related to the seasonal silicon cycle in this shallow, well-mixed ecosystem (Fig. 8). At the beginning of the productive period, diatom development leads to a severe depletion of silicic acid, and Del Amo et al. (1997) conclude that such a depletion causes the collapse of the spring bloom. As commonly observed in coastal ecosystems

Table 2. Average values of freshwater discharge (daily averages) by the Aulne and Elorn rivers and of nutrient concentrations in the Bay of Brest $\left(\right.$ Stn $R_{3}$ ) for each period

\begin{tabular}{lccccc|}
\hline & $\begin{array}{l}\text { Riverine discharge } \\
\left(\mathrm{m}^{3} \mathrm{~s}^{-1}\right)\end{array}$ & $\begin{array}{c}\mathrm{NO}_{3}{ }^{-} \\
(\mu \mathrm{M})\end{array}$ & $\begin{array}{c}\mathrm{NH}_{4}{ }^{+} \\
(\mu \mathrm{M})\end{array}$ & $\begin{array}{c}\mathrm{Si}(\mathrm{OH})_{4} \\
(\mu \mathrm{M})\end{array}$ & $\begin{array}{c}\mathrm{PO}_{4}{ }^{2-} \\
(\mu \mathrm{M})\end{array}$ \\
\hline Spring transition & 23 & 23.0 & 0.5 & 8.0 & 0.4 \\
Spring bloom & 44 & 8.6 & 0.3 & 2.0 & 0.1 \\
Second.ary blooms & 25 & 2.2 & 0.3 & 2.9 & 0.1 \\
Fall/winter & 45 & 13.9 & 0.8 & 6.9 & 0.4 \\
\hline
\end{tabular}

(e.g. Smetacek 1988), the bulk of the spring diatom bloom is not channeled through the pelagic food web due to the temporal mismatch with large macrozooplankton. In accordance with Bienfang et al. (1982), we hypothesize that the spring diatom population of the Bay of Brest might have rapidly settled at the watersediment interface at the end of the spring bloom due to Si limitation. Supporting this hypothesis are the higher BSi concentrations measured in bottom waters relative to surface waters during the spring bloom collapse (Fig. 3). In coastal upwelling ecosystems with diatom-dominated populations, export of biogenic silica from the photic layer feeds the 'silicate pump' described by Dugdale et al. (1995), which results in enhanced loss of silicate versus nitrogen from surface towards deep waters. In deep and stratified water ecosystems, such a 'silicate pump' reduces the availability of silicic acid in the euphotic layer, increasing its role as a limiting nutrient in surface waters. Deep waters become oppositely Si enriched by BSi dissolution, as compared to $\mathrm{N}$, which is rapidly recycled in the surface layer by heterotrophic activity (Levasseur \& Therriault 1987, Dugdale et al. 1995; Fig. 8). In the shallow ecosystem of the Bay of Brest, we hypothesize that the 'silicate pump' works conversely to the scenario described by Dugdale et al. (1995) and silicon trapping as BSi at the water-sediment interface prevents from the loss of Si out of the system. The wellmixed nature of this system, resulting from tidally induced vertical mixing, then allows silicic acid originating from gradual dissolution of biogenic silica of the settled frustules to be readily available for diatom development in surface waters during the remaining productive period (Fig. 8). This pattern complies with the spring silica budget estimated by Ragueneau et al. (1994) emphasizing the increase of Si recycling from the sediment-water interface with temperature from April to June. It also explains the observed increase of silicic acid that supports the secondary blooms (Table 2). Thus, Si recycling restricts the dramatic Silimiting period to a relatively short time interval and allows support of the high Si requirement of diatoms during summer, contrary to other stratified and deep water ecosystems where $\mathrm{Si}$ is trapped out of the euphotic zone after the spring bloom sedimentation.

There is evidence that $\mathrm{Si}$ retention in the sediments after the spring bloom applies to other coastal ecosystems, as described by Dugdale et al. (1995), although in those systems depth and stratification prevent the recycled silicic acid from reaching the surface layer. The silicic acid pump described by Dugdale et al. (1995) for stratified systems does not lead to an enhancement of the limit- 


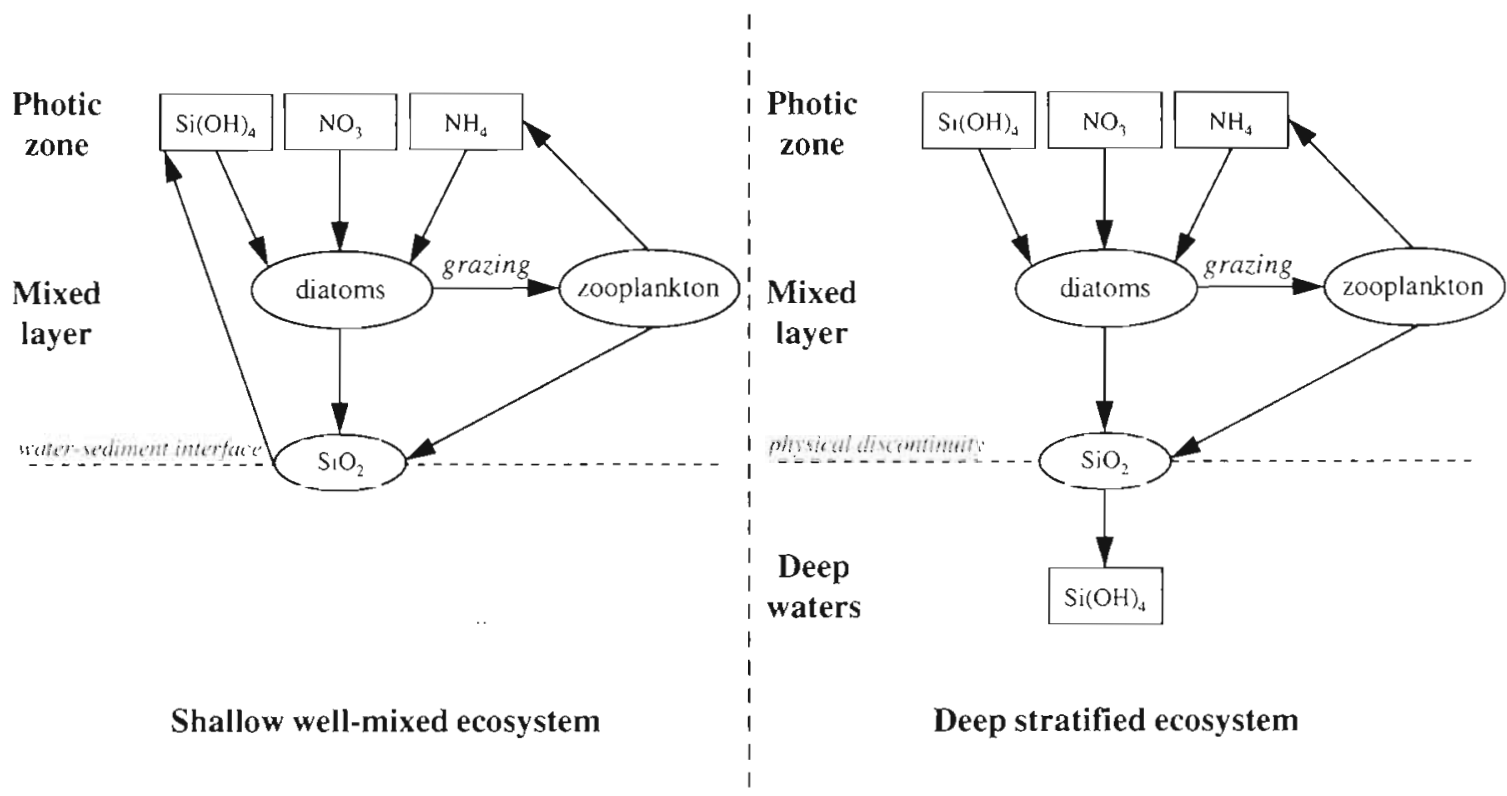

Fig. 8. Conceptual schemes of the silicic acid pump for oceanic ecosystems as described by Dugdale et al. (1995) (right panel), and as modified for shallow well-mixed ecosystems (left panel)

ing role of Si in shallow well-mixed ecosystems, but, on the contrary, to a prevention of Si limitation, i.e. the same mechanism leads to an opposite effect according to specific hydrodynamic conditions. This situation also applies for the nearshore well-mixed waters of the western English Channel where diatom blooms develop during spring tides, which increase watermixing and enable nutrient replenishment of the water column from the sediment-water interface (Ragueneau et al. 1996).

\section{Conclusion}

The overall phytoplankton dynamics of the Bay of Brest contrast with those reported for other N-disturbed ecosystems, as the decrease of the Si:DIN ratio related to the $\mathrm{N}$ enrichment of coastal waters is classically associated with a general decrease of microplankton and diatom abundance, favoring the development of smaller and non-siliceous populations (Officer \& Ryther 1980, Smayda 1990, Billen et al. 1991, Malej et al. 1995). Le Pape et al. (1996) showed that there is no acute response in the Bay of Brest to $\mathrm{N}$ enrichment in terms of primary productivity. At present, neither is there evidence that the observed winter surplus of nitrate as compared to silicic acid inputs (Del Amo et al. 1997) has dramatically affected the phytoplankton community structure of the Bay of Brest in terms of size structure and of diatom abundance relative to dinoflagellates. In terms of phytoplankton size structure, microplankton dominates during most of the productive period; its contribution to total biomass and to total primary production tends to decrease towards the end of the secondary blooms period, in favor of smaller size classes, which become important contributors from October to late March, probably due to their better adaptation to environmental conditions. Furthermore, because no previous data on the size structure of phytoplankton are available for the Bay of Brest ecosystem, conclusions cannot been drawn about potential long-term shifts from microplankton to nanoplankton as observed elsewhere in response to $\mathrm{N}$ and P enrichments (Revelante \& Gilmartin 1978, Malej et al. 1995). However, dinoflagellates ( $<$ and $>10 \mu \mathrm{m}$ ) increase at the spring bloom collapse and remain abundant during summer, with some non-desirable species emerging among them.

The original patterns of the biogeochemical cycles of Si and $\mathrm{N}$ in shallow well-mixed ecosystems prevent the appearance of a new production community dominated by dinoflagellates, contrary to what has been suggested by Billen et al. (1991) in the North Sea. The original mechanism of the 'silicate pump' in wellmixed ecosystems enables a high, diatom-dominated, summer production.

Acknowledgements. This research was supported by a Contrat de Bale grant awarded by the Communauté Urbaine de Brest. We thank Olivier Le Pape and Philippe Cann for their work at sea, as well as 4 anonymous referees for their helpful comments. Thanks are also due to captains, officers, and crew members of the Marine Nationale ships for their technical assistance at sea. This work is UMR CNRS 6539 contribution 97006. 


\section{LITERATURE CITED}

Anderson DM (1995) Toxic red tides and harmful algal blooms: a practical challenge in coastal oceanography. Rev Geophys Suppl: US Nat Rep Int Union Geodesy Geophys 1991-1994:1189-1200

Arthur CR, Rigler FH. (1967) A possible source of error in the ${ }^{14} \mathrm{C}$ method of measuring primary productivity. Limnol Oceanogr 12:121-124

Azam F, Fenchel T, Field JG, Gray JS, Meyer-Reil LA, Thingstad $F$ (1983) The ecological role of water-column microbes in the sea. Mar Ecol Prog Ser 10:257-263

Banse K, Falls CP, Hobson LA (1963) A gravimetric method for determining suspended matter in sea water using Millipore filters. Deep Sea Res 10:639-642

Bienfang PK, Harrison PJ, Quarmby LM (1982) Sinking rate response to depletion of nitrate, phosphate and silicate in four marine diatoms. Mar Biol 67:295-302

Billen G, Lancelot C, Meybeck M (1991) N, P, Si retention along the aquatic continuum from land to ocean. In: Mantoura RFC, Martin JM, Wollast R (eds) Ocean margin processes in global change. J Wiley \& Sons. New York. p $19-44$

Bodeanu N (1990) Microalgal blooms in the Romanian area of the Black Sea and contemporary eutrophication conditions. In: Smayda TJ, Shimizu Y (eds) Toxic phytoplankton hinnms in the Sea. Elsevier Science Publishers BV. Amsterdam, p 203-209

Caron DA (1991) Evolving role of protozoa in aquatic nutrient cycles. In: Reid PC, Turley CM, Burkill PH (eds) Protozoa and their role in marine processes. Springer-Verlag, Berlin, $\mathrm{p} 387-415$

Cloern JE (1996) Phytoplankton bloom dynamics in coastal ecosystems: a review with some general lessons from sustained investigation of San Francisco Bay, California. Rev Geophys 34:127-168

Conley DJ, Malone TC (1992) Annual cycle of dissolved silicate in Chesapeake Bay: implications for the production and fate of phytoplankton biomass. Mar Ecol Prog Ser 81. 121. 128

Del Amo Y, Le Pape O, Tréguer P, Quéguiner B, Ménesguen A, Aminot A (1997) Impacts of high-nitrate freshwater Inputs on macrotidal ecosystems. I. Seasonal evolution of nutrient limitation for the diatom-dominated phytoplankton of the Bay of Brest (France). Mar Ecol Prog Ser 161:213-224

Delmas D, Herbland A, Maestrini SY (1992) Environmental conditions which lead to increase in cell density of the toxic dinoflagellates Dinophysis $\mathrm{sp}$. in nutrient-rich and nutrient-poor waters of the French Atlantic coast. Mar Ecol Prog Ser 89:53-61

Delmas R, Tréguer P (1983) Evolution saisonnière des nutriments dans un écosystème eutrophe d'Europe Occidentale (la rade de Brest). Interactions marines et terrestres. Oceanol Acta 6:345-355

Doering PH, Oviatt CA, Beatty LL, Banzon VF, Rice R, Kelly SP, Sullivan BK. Frithsen JB (1989) Structure and function in a model coastal ecosystem: silicon, the benthos and eutrophication. Mar Ecol Prog Ser 52:287-299

Dugdale RC. Wilkerson FP, Minas HJ (1995) The role of a silicate pump in driving new production. Deep Sea Res 42 $697-719$

Egge JK, Aksnes DL (1992) Silicate as regulating nutrient in phytoplankton competition. Mar Ecol Prog Ser 83:281-289

Fahnenstiel GL, Redalje DG, Lohrenz SE (1994) Has the importance of photoautotrophic picoplankton been overestimated? Limnol Oceanogr 39:432-438
Fenchel T (1987) Ecology of protozoa - the biology of freeliving phagotrophıc protists. Springer-Verlag. Berlin

Fisher TR, Peele ER, Ammerman JW, Harding LW Jr (1992) Nutrient limitation of phytoplankton in Chesapeake Bay. Mar Ecol Prog Ser 82:51-63

Grall JR, Jacques G (1964) Etude dynamique et variations saisonnières du plancton de la région de Roscoff. IB Phytoplancton. Cah Biol Mar 5:432-455

Hagström A, Azam F, Andersson A, Wikner J, Rassoulzadegan F (1988) Microbial loop in an oligotrophic pelagic marine ecosystem: possible roles of cyanobacteria and nanoflagellates in the organic fluxes. Mar Ecol Prog Ser 49:171-178

Hansen J (1992) Prey size selection, feeding rates and growth dynamics of heterotrophic dinoflagellates with special emphasis on Gyrodinium spirale. Mar Biol 114:327-334

Larsson U, Hagström A (1982) Fractionated phytoplankton primary production, exudate release and bacterial production in a Baltic eutrophication gradient. Mar Biol 67 . $57-70$

Leakey RJG, Burkill PH, Sleigh MA (1992) Planktonic ciliates in Southampton water: abundance, biomass, production, and role in pelagic carbon flow. Mar Biol 114:67-83

Legendre L, Le Fèvre J (1989) Hydrodynamic singularities as controls of recycled versus export production in oceans. In: Berger WH, Smetacek VS, Wefer G (eds) Productivity of the ocean: present and past. Wiley, Chichester, p 49-63

Le Pape O, Del Amo Y, Ménesguen A, Amınot A, Quéguiner $B$, Tréquer P (1996) Resistance of a coastal ecosystem to increasing eutrophic conditions: the Bay of Brest (France), a semi-enclosed zone of Western Europe. Cont Shelf Res 16:1885-1907

Lessard EJ, Swift E (1985) Species-specific grazing rates of heterotrophic dinoflagellates in oceanic waters, measured with a dual-label radioisotope technique. Mar Biol 87 : $289-296$

Levasseur ME, Therriault JC (1987) Phytoplankton biomass and nutrent dynamics in a tidally induced upwelling: the role of the $\mathrm{NO}_{3} \mathrm{SiO}_{4}$ ratio. Mar Ecol Prog Ser 39:87-97

Lignell R (1992) Problems in filtration fractionation of ${ }^{14} \mathrm{C}$ primary productivity samples. Limnol Oceanogr 37:172-178

Longhurst A, Sathyendranath S, Platt T, Caverhill C (1995) An estimate of global primary production in the ocean from satellite radiometer data. J Plankton Res 17:1245-1271

Lund JWG, Kipling C, Le Cren ED (1958) The inverted microscope method of estimating algal numbers and the statistical basis of estimations by countıng. Hydrobiologia 11: $143-178$

Malej A, Mozetic P, Malacic V, Terzic S, Ahel M (1995) Phytoplankton responses to freshwater inputs in a small semienclosed gulf (Gulf of Trieste, Adriatic Sea). Mar Ecol Prog Ser 120:11.1-121

Martin-Jezéquel V (1983) Facteurs hydrologiques el phytoplancton en baie de Morlaix (Manche Occidentale). Hydrobiologia 102:131-143

Meybeck M. Helmer R (1989) The quality of nvers: from pristine stage to global pollution. Paleogeogr Paleoclim Paleoecol 75:283-309

Michaels AF, Silver MW (1988) Primary production, sinking fluxes and the microbial food web. Deep Sea Res 35: $473-490$

Nelson DM, Dortch Q (1996) Silicic acıd depletion and silıcon limitation in the plume of the Mississippi River: evidence from kinetic studies in spring and summer. Mar Ecol Prog Ser 136:163-178

Officer CB, Ryther JH (1980) The possible importance of silicon in marine eutrophication. Mar Ecol Prog Ser 3:83-91 
Quéguiner B (1982) Variations qualitatives et quantitatives du phytoplancton dans un écosystème eutrophe fortement soumis aux effets des marées: la rade de Brest. PhD dissertation, Université de Bretagne Occidentale, Brest, p 123

Quéguiner B, Tréguer P (1984) Studies on the phytoplankton in the Bay of Brest (Western Europe). Seasonal variation in composition, biomass and production in relation to hydrological and chemical features (1981-1982). Bot Mar 27. $449-459$

Ragueneau O, De Blas Varela E, Tréguer P, Quéguiner B, Del Amo $Y(1994)$ Phytoplankton dynamics in relation to the brogeochemical cycle of silicon in a coastal ecosystem of western Europe. Mar Ecol Prog Ser 106:157-172

Ragueneau O, Quéguiner B, Tréguer P (1996) Contrast in biological responses to tidally induced vertical mixing for two macrotidal ecosystems of Western Europe. Estuar Coast Shelf Sci 42:645-665

Ragueneau O, Treguer P (1994) Determination of biogenic slica in coastal waters: applicability and limits of the alkaline digestion method. Mar Chem 45:43-51

Revelante N, Gilmartin M (1976) The effect of Po river discharcu on phytoplankton dynamics in the northern Adriatic Sca. Mar Biol 34:259-271

Revelante N, Gilmartin M (1978) Characteristics of the microplankton and nano-plankton communities of an Australian coastal plain estuary. Aust J Mar Freshwat Res 29:9-18

Sellner KG, Kachur ME (1987) Phytoplankton: relationships

Editorial responsibility: Otto Kinne (Editor), Oldendorf/Luhe, Germany between phytoplankton, nutrients, oxygen flux and secondary producers. In: Heck KL Jr (ed) Lecture notes on coastal and estuarine studies, ecological studies in the middle reach of Chesapeake Bay. Springer-Verlag, New York, p 12--37

Sieburth JM. Smetacek V, Lenz J (1978) Pelagic ecosystem structure: heterotrophic compartments of the plankton and their relationship to plankton size fractions. Limnol Oceanogr 23:1256-1263

Smayda TJ (1990) Novel and nuisance phytoplankton blooms in the sea: evidence for a global epidemic. In: Granéli $E$ (ed) Toxic marine phytoplankton. Elsevier Science Publishing Co, New York, p 29-40

Smetacek V (1988) Plankton characteristics. In: Postma H. Zijlstra JJ (eds) Ecosystems of the world 27, Continental shelves. Elsevier, Ansterdam, p 93-130

Tsuda A. Sugisakı H, Takahashi K, Furuya K (1994) Succession of pelagic organisms in the size-range $0.5-200 \mu \mathrm{m}$ during a diatom bloom in Otsuchi Bay, Japan. Estuar Coast Shelf Sci 39:173-184

Utermöhl M (1931) Über das umgekehrte Mikroskop. Arch Hydrobiol Beih Ergeb Plankton 22:643-645

van Bennekom AJ, Gieskes WWC, Tijssen SB (1975) Eutrophication of Dutch coastal waters. Proc R Soc Lond Ser B Biol Scl 189:359-374

Wafar MVM, Le Corre P, Birrien JL (1983) Nutrients and primary production in permanently well-mixed temperate coastal waters. Estuar Coast Shelf Sci 17:431-446

Submitted: May 6, 1996; Accepted: September 9, 1997 Proofs received from author(s): December 15, 1997 